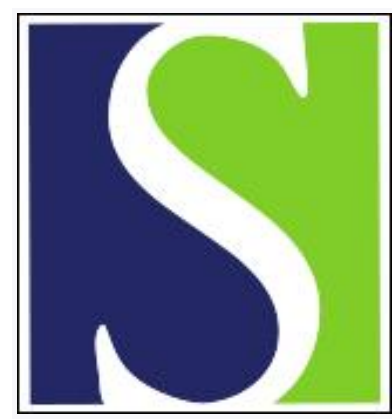

Scand J Work Environ Health 2011;37(2):159-167

https://doi.org/10.5271/sjweh.3087

Published online: 07 Sep 2010, Issue date: Mar 2011

Immunoglobulin E-mediated sensitization to pine and beech dust in relation to wood dust exposure levels and respiratory symptoms in the furniture industry

by Schlünssen V, Kespohl S, Jacobsen G, Raulf-Heimsoth M, Schaumburg I, Sigsgaard T

Affiliation: Department of Environmental and Occupational Medicine, School of Public Health, Aarhus University, Bartholins Allé 2, 8000 Aarhus C, Denmark. vs@mil.au.dk

Key terms: beech wood; exposure; furniture industry; IgE; IgE-mediated allergy; immunoglobulin E; occupational asthma; pine wood; respiratory symptom; wood dust; wood dust sensitization; wood industry

This article in PubMed: www.ncbi.nlm.nih.gov/pubmed/20820750 


\title{
Immunoglobulin E-mediated sensitization to pine and beech dust in relation to wood dust exposure levels and respiratory symptoms in the furniture industry
}

\author{
by Vivi Schlünssen, PhD, ${ }^{1}$ Sabine Kespohl, PhD, ${ }^{2}$ Gitte Jacobsen, PhD, ${ }^{1}$ Monika Raulf-Heimsoth, PhD, ${ }^{2}$ \\ Inger Schaumburg, PhD, ${ }^{3}$ Torben Sigsgaard, $P h D^{1}$
}

\begin{abstract}
Schlünssen V, Kespohl S, Jacobsen G, Raulf-Heimsoth M, Schaumburg I, Sigsgaard T. Immunoglobulin E-mediated sensitization to pine and beech dust in relation to wood dust exposure levels and respiratory symptoms in the furniture industry. Scand J Work Environ Health. 2011;37(2):158-167. doi:10.5271/sjweh.3087
\end{abstract}

\begin{abstract}
Objectives Wood dust exposure may cause Immunoglobulin E (IgE)-mediated allergic diseases. Our objectives were to estimate pine and beech dust sensitization rates among woodworkers and a reference group, explore the association between exposure and sensitization and between sensitization and respiratory symptoms, and finally investigate the impact of proteinogenic specific $\operatorname{IgE}(\mathrm{s} \operatorname{IgE})$ epitopes on respiratory symptoms.

Methods In a Danish study among 52 furniture factories and 2 reference factories, we evaluated the workers' asthma and rhinitis status using questionnaires and blood samples collected from 1506 woodworkers and 195 references. Workers with asthma symptoms $(\mathrm{N}=298)$, a random study sample $(\mathrm{N}=399)$ and a random rhinitis sample $(\mathrm{N}=100)$ were evaluated for IgE-mediated sensitization to pine and beech dust.

Results The prevalence of pine and beech sensitization among current woodworkers was 1.7 and 3.1\%, respectively. No differences in sensitization rates were found between woodworkers and references, but the prevalence of wood dust sensitization was dose-dependently associated with the current level of wood dust exposure. No relation was observed between wood dust sensitization per se and respiratory symptoms. Only symptomatic subjects had proteinogenic IgE epitopes to pine. Increased odds ratios for sIgE based on proteinogenic epitopes to beech and respiratory symptoms were found, although they were not statistically significant.
\end{abstract}

Conclusions Sensitization rates to pine and beech were the same for woodworkers and references but dependent on the current wood dust exposure level. The importance of beech and pine wood sensitization is limited, but may be of clinical significance for a few workers if the $\operatorname{IgE}$ epitopes are proteinogenic.

Key terms beech wood; IgE; IgE-mediated allergy; occupational asthma; pine wood; wood dust sensitization; wood industry

Approximately 3.6 million workers in the European Union are exposed to wood dust on a regular basis (1). Worldwide, 12000 tree species exist and more than 1000 are used for commercial purposes (2). Wood dust is recognized as a human carcinogen $(2,3)$. Beside the carcinogenic effect, a number of epidemiological studies have identified wood dust as a risk factor for asthma or asthma symptoms (4-6), nasal impairment $(7,8)$, and acute or chronic impairment of lung function (8-10) all diseases consistent with both an allergic and a nonallergic origin.
For some wood types, the presence of Immunoglobulin E ( $\mathrm{IgE}$ ) sensitization has been demonstrated for individuals or minor groups of patients, mainly for tropical trees like mukali (11) and pao marfin (12), but also for trees growing in the temperate zones such as beech and pine (13).

The extent of IgE-mediated wood dust sensitization is unclear although it seems from the few existing epidemiological studies that only a minor part of woodworkers are sensitized (14-16). On the other hand, evaluations of subjects investigated for allergic asthma

1 Department of Environmental and Occupational Medicine, School of Public Health, Aarhus University, Denmark.

2 Institute of Prevention and Occupational Medicine, German Social Accident Insurance, Institute of the Ruhr University Bochum (IPA), Department of Allergology/Immunology, Germany.

3 Neuro Centre, Aarhus University Hospital, Denmark.

Correspondence to: Vivi Schlünssen, Department of Environmental and Occupational Medicine, School of Public Health, Aarhus University, Bartholins Allé 2, 8000 Aarhus C, Denmark. [E-mail: vs@mil.au.dk] 
or rhinitis suggest that $\operatorname{IgE}$ sensitization plays a role with the wood species used in the Nordic countries (17).

Western red cedar is a well-documented cause of occupational asthma. The aetiological agent is the low molecular weight (LMW) agent plicatic acid (18). In a single study, specific IgE (sIgE) was documented among $44 \%$ ( 8 out of 18 ) with a positive specific provocation test for plicatic acid (19), but further studies have shown IgE-mediated sensitization to be of minor importance for the aetiology of western red cedar asthma $(20,21)$.

Dust from obeche, which has higher protein content (22), may on the other hand be a strong IgE-mediated sensitizer. In a smaller study, 7 out of 10 symptomatic wood-workers were sensitized, and a $38 \mathrm{kDa}$ class I chitinase obeche wood allergen was identified (22).

A cohort study in the Danish furniture industry investigated the relation between wood dust exposure and respiratory diseases. The exposure was mostly to softwood (pine, spruce) and wooden boards. We have reported dose-response relationships between inhalable wood dust concentration and respiratory symptoms (23-25), acute nasal mucosal swelling (23), increased bronchial hyper-responsiveness (25) and acute decline in lung function (26). Furthermore, we have shown an increased incidence of respiratory symptoms among female woodworkers (27).

Earlier in a non-random subsample, we have demonstrated that only a small amount of woodworkers were sensitized to pine dust, despite the regular use of pine in the Danish furniture industry (28).

The objectives of the present study were to estimate pine and beech dust sensitization rates among current and prior woodworkers and references, explore the association between exposure and sensitization and between sensitization and respiratory symptoms, and finally investigate the impact of proteinogenic sIgE epitopes on respiratory symptoms.

\section{Methods}

\section{Study population}

The study population is described in detail elsewhere $(24,29)$, but in brief the 1997 study included 54 furniture factories or more than $90 \%$ of all furniture workers employed in Viborg County. The study population was workers employed in the woodworking, assembly, or stock departments. Additionally three factories (two producing refrigerators and one producing hearing aids) in the same area were selected as references. The 2003 study was a follow up to the 1997 study, supplemented with all new factories emerging in Viborg County in 1997-2003, and included 52 furniture factories or more than $95 \%$ of all furniture workers in Viborg County, of which 38 factories also participated in the 1997 study. Additionally 2 of the 3 reference were included. In total, 1377 (68\%) woodworkers (829 current and 548 prior) and $297(63 \%)$ references participated in both 1997 and 2003, together with 1104 current woodworkers only participating in 2003 (78\% participation rate).

Thus, the source population is woodworkers (prior or current) in Viborg county. Of this population of 2481 woodworkers (1933 current and 548 prior) and 297 references, we collected a blood sample from 1506 woodworkers (1203 current and 497 prior) and 195 references, in total 1701 subjects. Reasons for not having a blood sample drawn were (i) closing of the factory ( $\mathrm{N}=155)$, (ii) absence on the day of the blood sampling mainly due to shift work ( $\mathrm{N}=646$ ), or (iii) refusal to have a blood sample drawn $(\mathrm{N}=276)$.

From the pool of 1701 subjects with blood samples, all 298 with asthma symptoms and 100 suffering from rhinitis (randomly chosen) were collected, together with a random sample of 399 ( 289 current and 72 prior woodworkers and 38 references). The random sample included 96 of the 298 subjects with asthma symptoms, resulting in 701 subjects (hereafter called "total sample") for further analysis of sIgE sensitization to pine and beech dust. A flow chart of the study is shown in figure 1.

All participants gave informed consent; the Ethic Committee for Viborg County, Denmark, approved the protocol.

\section{Health outcomes}

A modified British Medical Research Council (BMRC) questionnaire (30) including key European Community Respiratory Health Survey (ECRHS) questions on asthma (31) with additional questions on allergy, coughing, asthma, rhinitis, smoking and occupational history was distributed at follow-up. "Ever asthma" was defined as

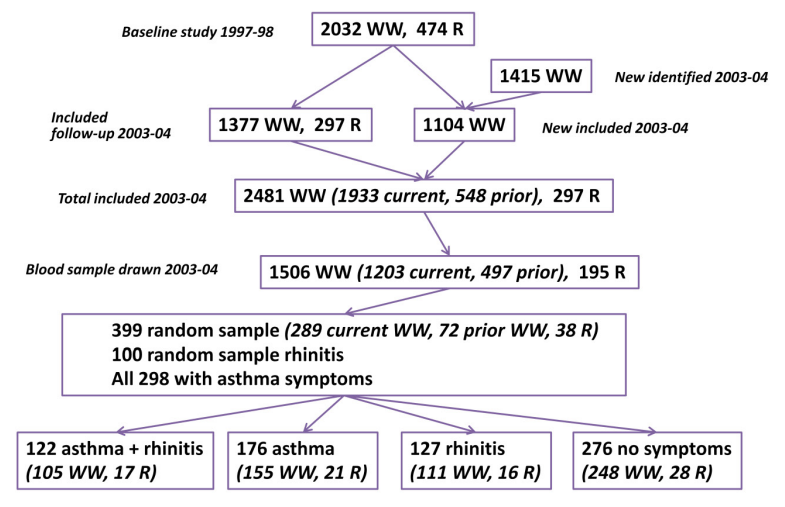

Figure 1. Flowchart of study. [WW=woodworkers; R=references.] 
ever having self-reported asthma. "Asthma symptoms" were defined if the subject answered yes to $\geq 1$ group A question (physician-diagnosed asthma, current asthma, ever asthma, ever wheezed) and $\geq 2$ group B questions (use of asthma drugs, ever chest tightness, ever wake up with chest tightness, wake up wheezing, morning cough, wake up coughing, wheeze when exposed to cold air or pollen or animals, wheeze when exercise) or $\geq 2$ group A questions (24). "Current asthma" was defined, according to the ECRHS definition, as having an attack of asthma in the last 12 months or use of medication for asthma (31). "Rhinitis" was defined as answering yes to having $\geq 2$ nasal symptoms (rhinorrhoea, nasal itching, nasal congestion, or sneezing) $\geq 2$ days a week during the last year or daily in periods. "Work-related asthma or rhinitis symptoms" were defined as self-assessed worsening of symptoms in relation to work or relief of symptoms on weekends or holidays. "Smokers" were defined as current smokers or ex-smokers for $<2$ years, as recent ex-smokers are expected to have remaining acute or sub-acute effect (eg chronic bronchitis, bronchial hyper-responsiveness).

Lab technicians drew blood samples at the factories or hospital departments. The serum samples were stored at $-20^{\circ} \mathrm{C}$ for $1-5$ months and then sent to the Institute of the Ruhr University Bochum for further analysis, where they were stored at $-80^{\circ} \mathrm{C}$.

Atopic status was defined as a positive reaction to Phadiatop ${ }^{\circledR}$ (former Pharmacia AB, Uppsala, Sweden) [sIgE to $\geq 1$ of 10 common respiratory allergens: birch, mugwort, horse, dog, cat, house-dust mites (Dermatophagoides farinae and Dermatophagoides pteronyssinus), mould (Cladosporium herbarum), grass (Artemisia vulgaris) and lichwort (Parietaria officinalis)].

\section{Exposure Assessment}

Personal dust samplings were carried out in both the 1997 and 2003 study with passive dust monitors as described previously (32). In brief, the method is based on measuring light extinction before and after sampling on transparent sticky foils. The change in light extinction was reported as dust-covered foil area and converted to equivalent inhalable dust by linear regression models based on previous and present calibration measurements $(29,33)$.

Job-exposure matrices (JEM), based on factory size and task, were constructed in the 1997 (12 groups, 2217 measurements, 1581 individuals) and 2003 study (7 groups, 1355 measurements, 1044 individuals) (27). Personal JEM estimates for baseline and current inhalable exposures were for subjects present at each sampling occasion categorized into three groups, with two quartiles in the intermediate group; due to few groups and unequal distribution between groups, the cut-off points were not precisely 25 and $75 \%$.

Preparation of pine and beech wood-specific ImmunoCAP

Pine and beech wood were collected from workplaces, sawed into dust and used for aqueous and ethanolic extraction as described by Kespohl et al (34). Wood dust extracts were biotinylated with D-biotinoyl- $\mu \mathrm{l}-$ aminocaproic acid N-hydroxysuccinimide ester (NHSBiotin) and $50 \mu \mathrm{l}$ biotinylated wood extracts were loaded on Streptavidin-ImmunoCAP ${ }^{\circledR}$ o221 (Phadia AB, Uppsala, Sweden) as described previously (35). Quality control was performed with sera of pine and beech wood-sensitized workers as positive controls and sera of non-sensitized woodworkers and ImmunoCAP diluent as negative controls.

\section{Determination of specific Immunoglobin $\mathrm{E}$}

All 701 sera were tested for SIgE to pine and beech wood dust with ImmunoCAP ${ }^{\circledR} 250$ (Phadia AB, Uppsala, Sweden) using the specific tailored ImmunoCAPs. SIgE antibody values $\geq 0.35 \mathrm{kU}_{\mathrm{A}} / 1$ were considered positive. To characterize sIgE binding to cross-reactive carbohydrate determinants (CCD), samples with allergen-sIgE antibody $\geq 0.35 \mathrm{kU}_{\mathrm{A}} / 1$ to any wood allergen were tested for sIgE to the three commercially available CCD: horseradish peroxidase (HRP; Ro400), bromelain (k202) and $\operatorname{MUXF}^{3}$ (Ro214). Total allergen-sIgE antibody values $\geq 0.35 \mathrm{kU}_{\mathrm{A}} / 1$ were considered positive.

For differentiation between proteinogenic and glycogenic IgE-binding epitopes, sIgE binding to beech and pine wood was furthermore analyzed in a competitive inhibition assay with the glycogenic substance HRP as inhibitor (34). The reduction of $\operatorname{IgE}$ binding to wood allergen by HRP was calculated as percentage difference between phosphate buffered saline control $(100 \%)$ and HRP inhibition.

\section{Statistical analysis}

Data were analyzed using SPSS statistical software for Windows, version 15.0 (SPSS Inc, Chicago, IL, USA). Univariate analyses were undertaken for categorical variables using $\chi^{2}$ tests. Logistic regression analysis was used to evaluate associations between sensitization and symptoms. We included as confounders: smoking (defined as present smokers or ex-smokers for $<2$ years), age ( 5 categories), gender, and atopy. Unless otherwise stated, the level of significance was $\mathrm{P}<0.05$, two-sided.

\section{Results}

The characteristics of the total and random samples by exposure status are listed in table 1. 
Table 1. Characteristics of the total sample and the random sample by current and prior woodworkers and reference workers. [M=median; R=range]

\begin{tabular}{|c|c|c|c|c|c|c|c|c|c|c|c|c|c|c|c|c|c|c|c|c|c|c|c|}
\hline \multirow[t]{3}{*}{ Characteristics } & \multicolumn{11}{|c|}{ Total sample, N = 701} & \multicolumn{12}{|c|}{ Random sample, N = 399} \\
\hline & \multicolumn{4}{|c|}{$\begin{array}{l}\text { Current } \\
\text { woodworker } \\
(\mathrm{N}=479)\end{array}$} & \multicolumn{4}{|c|}{$\begin{array}{c}\text { Prior } \\
\text { woodworker } \\
(\mathrm{N}=140)\end{array}$} & \multicolumn{3}{|c|}{$\begin{array}{l}\text { Reference } \\
\text { worker } \\
(\mathrm{N}=82)\end{array}$} & \multicolumn{4}{|c|}{$\begin{array}{c}\text { Current } \\
\text { woodworker } \\
(\mathrm{N}=289)\end{array}$} & \multicolumn{4}{|c|}{$\begin{array}{c}\text { Prior } \\
\text { woodworker } \\
(\mathrm{N}=72)\end{array}$} & \multicolumn{4}{|c|}{$\begin{array}{c}\text { Reference } \\
\text { worker } \\
(\mathrm{N}=38)\end{array}$} \\
\hline & $\mathrm{N}$ & $\%$ & M & $\mathrm{R}$ & $\mathrm{N}$ & $\%$ & $\mathrm{M}$ & $\mathrm{R}$ & $\mathrm{N}$ & $\%$ & $\mathrm{M}$ & $\mathrm{N}$ & $\%$ & M & $\mathrm{R}$ & $\mathrm{N}$ & $\%$ & M & $\mathrm{R}$ & $\mathrm{N}$ & $\%$ & M & $\mathrm{R}$ \\
\hline \multicolumn{24}{|l|}{ Personal } \\
\hline Male & 369 & 77 & & & 109 & 78 & & & $35^{a}$ & 43 & & 221 & 77 & & & 62 & 86 & & & $19^{a}$ & 50 & & \\
\hline Age in years & & & \multicolumn{2}{|c|}{$4218-68$} & & & 46 & $24-69$ & & & 43 27-67 & & & \multicolumn{2}{|c|}{42 18-68 } & & & 47 & $25-69$ & & & \multirow{3}{*}{\multicolumn{2}{|c|}{$4127-65$}} \\
\hline Smokers ${ }^{b}$ & 210 & 46 & & & 67 & 51 & & & 45 & 57 & & 119 & 42 & & & 23 & 43 & & & 18 & 49 & & \\
\hline $\begin{array}{l}\text { Smokers, } \\
\geq 20 / \text { day }\end{array}$ & 103 & 47 & & & 37 & 49 & & & 21 & 44 & & 57 & 46 & & & 17 & 50 & & & 6 & 32 & & \\
\hline \multicolumn{24}{|l|}{ Exposure } \\
\hline $\begin{array}{l}\text { Work mostly } \\
\text { with pine }{ }^{c}\end{array}$ & 270 & 57 & & & 94 & 70 & & & . & & & 164 & 57 & & & 46 & 69 & & & . & & & \\
\hline $\begin{array}{l}\text { Work mostly } \\
\text { with beechd }\end{array}$ & 69 & 14 & & & 18 & 13 & & & . & & & 37 & 13 & & & 8 & 12 & & & . & & & \\
\hline $\begin{array}{l}\text { Years in wood } \\
\text { industry }\end{array}$ & & & 13 & $0-43$ & & & 12 & $0-46$ & . & & & & & 13 & $0-43$ & & & 9 & $1-40$ & . & & & \\
\hline \multicolumn{24}{|l|}{ Health } \\
\hline Atopy ${ }^{e}$ & 140 & 29 & & & 34 & 24 & & & 34 & 24 & & 69 & 24 & & & 15 & 21 & & & 8 & 21 & & \\
\hline $\begin{array}{l}\text { Current } \\
\text { asthma }\end{array}$ & 78 & 16 & & & $38^{f}$ & 27 & & & 18 & 23 & & $18^{g}$ & 6 & & & $0^{g}$ & 14 & & & 4 & 11 & & \\
\hline $\begin{array}{l}\text { Asthma } \\
\text { symptoms }\end{array}$ & 190 & 40 & & & 70 & 50 & & & 38 & 46 & & $45^{g}$ & 16 & & & $16^{g}$ & 22 & & & $7 g$ & 18 & & \\
\hline $\begin{array}{l}\text { Work-related } \\
\text { asthma } \\
\text { symptoms }\end{array}$ & 43 & 9 & & & 17 & 13 & & & 5 & 6 & & $14^{g}$ & 5 & & & 4 & 6 & & & 1 & 3 & & \\
\hline $\begin{array}{l}\text { Rhinitis } \\
\text { symptoms }\end{array}$ & 163 & 34 & & & 53 & 38 & & & 33 & 40 & & $64^{g}$ & 22 & & & $14^{g}$ & 19 & & & $8^{g}$ & 21 & & \\
\hline $\begin{array}{l}\text { Work-related } \\
\text { rhinitis } \\
\text { symptoms }\end{array}$ & 88 & 19 & & & 17 & 13 & & & 10 & 12 & & $34 \mathrm{~g}$ & 12 & & & 3 & 5 & & & 3 & 8 & & \\
\hline
\end{tabular}

a $P<0.01$ between reference and woodworker

b Defined as current smokers or ex-smokers for more than two years prior to the 2003 study.

c Woodworker using mainly pine (Pinus Sylvestris).

d Woodworker using mainly beech (Fagus spec).

e Defined as a positive Phadiatop $®$.

${ }^{f} \mathrm{P}<0.05$ between prior and current woodworker.

g $\mathrm{P}<0.05$ between random sample and total sample by exposure status.

There were less reference male workers compared to male woodworkers in both the total (43 versus $77-78 \%$ ) and random sample (50 versus $77-86 \%$ ). No significant differences with regard to age (median 42-47 years), smoking status $(42-57 \%$, of which nearly $50 \%$ heavy smokers) or atopic status (21-29\%) were seen between the groups. No significant difference in exposure characteristics for woodworkers was seen between groups. Between $57-70 \%$ of the woodworkers processed mostly pine wood and $12-14 \%$ processed mostly beech wood.

As expected, the prevalence of respiratory symptoms was higher in the total compared to the random sample. In the total sample, more prior woodworkers had asthma (27\%) compared to current woodworkers $(16 \%)$, and the same tendency was seen in the random sample (14 versus 6\%). Otherwise no significant differences in symptom status were observed between current and prior woodworkers. In the random sample of current woodworkers, the prevalence of respiratory symptoms ranged from $5 \%$ (work-related asthma symptoms) to $22 \%$ (rhinitis symptoms).

The median (minimum-maximum) inhalable dust level was decreased from $0.93(0.37-1.61) \mathrm{mg} / \mathrm{m}^{3}$ in $1997-1998$ to $0.55(0.28-0.91) \mathrm{mg} / \mathrm{m}^{3}$ in $2003-2005$.

We measured $\operatorname{sIgE}$ concentrations $\geq 0.35 \mathrm{kU}_{\mathrm{A}} / 1$ to wood dust in $26(3.7 \%)$ subjects. Of these positive samples, 23 showed SIgE to beech wood and 18 had SIgE to pine wood; 15 samples had sIgE for both beech and pine wood. Mean (standard deviation) SIgE to pine dust was $1.5(3.4) \mathrm{kU}_{\mathrm{A}} / 1$, where as for beech it was $2.2(2.7) \mathrm{kU}_{\mathrm{A}} / 1$. SIgE to pine and beech was strongly correlated to atopy. All subjects with sIgE to beech wood were atopic. Only one subject with sIgE to pine wood was non-atopic.

Table 2 shows prevalence of sensitization to pine, 
beech, and common inhalant allergens in the random sample of current woodworkers and among subjects from the total sample with current asthma, asthma symptoms, work-related asthma symptoms, rhinitis symptoms and work-related rhinitis symptoms.

Sensitization to common allergens was significantly increased among subjects with respiratory symptoms, most pronounced for asthma and rhinitis symptoms (44\%), work-related asthma symptoms (45\%) and current asthma (41\%) compared to the group without symptoms $(17 \%)$.

The prevalence of pine and beech sensitization among a random sample of current woodworkers was 1.7 and $3.1 \%$, respectively. There was no significant difference in the prevalence of wood dust sensitization between the symptomatic groups and group with no symptoms [eg, 3.3 versus $1.4 \%(\mathrm{P}=0.15)$ for pine sensitization and 3.1 versus $3.6 \%(\mathrm{P}=0.67)$ for beech sensitization].

Table 3 presents the results on associations between wood dust exposure and sensitization to pine, beech and common allergens. No significant association was seen between sensitization and exposure status (never, prior, currently exposed) or duration of employment in the wood industry among woodworkers. Prevalence of sensitization to both pine and beech wood was associated in a dose-dependent way with current wood dust exposure, being one order of magnitude higher in the highest exposed group. There was a tendency towards a dose-dependent relation between exposure level at baseline (1997-1998) and sensitization to pine and beech dust. No relation between $\mathrm{sIgE}$ to pine and processing of pine wood on a regular basis (almost daily or daily) was seen. The same was true for sIgE to beech wood and regular processing of beech wood (results not shown).

Additional SIgE testing for CCD showed that 19 of all 26 wood dust-sensitized workers $(73 \%)$ recognized glycogenic epitopes (34). Proteinogenic epitopes to wood allergens were noted if $\operatorname{sgE}$ binding to pine or beech wood was not reduced by HRP in inhibition tests. The numbers were 9 for beech dust and 8 for pine dust.
In table 4 , adjusted odds ratios (OR) for respiratory symptoms and both total wood dust sensitization and proteinogenic sensitizations are given. Asthma symptoms were negatively associated with total beech SIgE, with OR $0.2[95 \%$ confidence interval $(95 \%$ CI) $0.1-0.7]$. Besides this, no significant association between respiratory symptoms and total SIgE for pine or beech was found. Atopy was strongly related to respiratory symptoms for both pine and beech models, with OR between 4.8 (95\% CI 2.5-9.1) (work-related asthma symptoms to beech) and 2.1 (95\% CI 1.2-3.6) (work- related rhinitis symptoms to pine). Current smoking was associated with asthma and rhinitis symptoms and work-related asthma symptoms, with OR between 2.1 (95\% CI 1.5-3.0) (asthma symptoms) and 1.4 (95\% CI 1.0-2.0) (rhinitis symptoms).

Only symptomatic subjects had proteinogenic sIgE epitopes to pine and OR were infinity for all models (not included in table 4). No significant associations between respiratory symptoms and proteinogenic epitopes to beech were found, but OR calculated on proteinogenic sensitization were increased for all symptom groups compared to the association between total beech $\operatorname{sigE}$ and respiratory symptoms.

\section{Discussion}

This study shows a low sIgE sensitization rate to beech (3.1\%) and pine $(1.7 \%)$ dust among a random sample of current Danish woodworkers, with wood dust sensitization almost only among atopic subjects.

A low sensitization rate for pine $\operatorname{sIgE}(2.9 \%)$ was shown in the 1997 study among a non-randomized subpopulation of 483 subjects (28). Our result supports data from other epidemiological studies on pine dust sensitization. Cormier et al (15) found $4.7 \%$ of 1200 Canadian sawmill workers to be sensitized to pine dust. In a Swedish study of 139 woodwork teachers, only 2

Table 2. Prevalence of sensitization to pine, beech, and common inhalant allergens (Phadiatop $®$ ) in the random sample of current woodworkers (WW) and among subjects from the total sample with current asthma, asthma symptoms, work-related asthma symptoms, rhinitis symptoms and work-related rhinitis symptoms

\begin{tabular}{|c|c|c|c|c|c|c|c|c|c|c|c|c|c|c|c|c|}
\hline \multirow[t]{2}{*}{ Positive Specific IgE } & \multicolumn{2}{|c|}{$\begin{array}{c}\text { Random } \\
\text { sample, } \\
\text { current WW } \\
(\mathrm{N}=289)\end{array}$} & \multicolumn{2}{|c|}{$\begin{array}{c}\text { No } \\
\text { symptoms } \\
(\mathrm{N}=276)\end{array}$} & \multicolumn{2}{|c|}{$\begin{array}{l}\text { Current } \\
\text { asthma } \\
(\mathrm{N}=134)\end{array}$} & \multicolumn{2}{|c|}{$\begin{array}{l}\text { Only asthma- } \\
\text { symptoms } \\
(\mathrm{N}=176)\end{array}$} & \multicolumn{2}{|c|}{$\begin{array}{c}\text { Only rhinitis } \\
\text { symptoms } \\
(\mathrm{N}=127)\end{array}$} & \multicolumn{2}{|c|}{$\begin{array}{l}\text { Asthma and } \\
\text { rhinitis } \\
\text { symptoms } \\
(\mathrm{N}=122)\end{array}$} & \multicolumn{2}{|c|}{$\begin{array}{c}\text { Work-related } \\
\text { asthma } \\
\text { symptoms } \\
(\mathrm{N}=65)\end{array}$} & \multicolumn{2}{|c|}{$\begin{array}{c}\text { Work-related } \\
\text { rhinitis } \\
(\mathrm{N}=115)\end{array}$} \\
\hline & $\mathrm{N}$ & $\%$ & $\mathrm{~N}$ & $\%$ & $\mathrm{~N}$ & $\%$ & $\mathrm{~N}$ & $\%$ & $\mathrm{~N}$ & $\%$ & $\mathrm{~N}$ & $\%$ & $\mathrm{~N}$ & $\%$ & $\mathrm{~N}$ & $\%$ \\
\hline Common allergens & 69 & 23.9 & 47 & 17.0 & $55^{\mathrm{a}}$ & 41 & $57^{\text {a }}$ & 32.4 & $35^{\mathrm{a}}$ & 27.6 & $54^{a}$ & 44.3 & 29 & 44.6 & 35 & 30.4 \\
\hline Pine dust & 5 & 1.7 & 4 & 1.4 & 7 & 5.2 & 5 & 2.8 & 5 & 3.9 & 4 & 3.3 & 3 & 4.6 & 3 & 2.6 \\
\hline Beech dust & 9 & 3.1 & 10 & 3.6 & 7 & 5.2 & 4 & 2.3 & 4 & 3.1 & 5 & 4.1 & 4 & 6.2 & 3 & 2.6 \\
\hline
\end{tabular}

${ }_{a} \mathrm{P}<0.05$ ( $\chi^{2}$ test) between group and references (subjects with no symptoms) 
Table 3. Prevalence of sensitization to pine, beech and common allergens in relation to wood dust exposure among 479 current woodworkers, 140 prior woodworkers and 82 never-exposed references

\begin{tabular}{|c|c|c|c|c|c|c|c|}
\hline \multirow[t]{2}{*}{ Wood dust exposure } & \multirow[b]{2}{*}{$\mathrm{N}$} & \multicolumn{2}{|c|}{$\begin{array}{l}\text { Specific IgE } \\
\text { pine }\end{array}$} & \multicolumn{2}{|c|}{$\begin{array}{l}\text { Specific IgE } \\
\text { beech }\end{array}$} & \multicolumn{2}{|c|}{$\begin{array}{l}\text { Specific IgE } \\
\text { common inhalant } \\
\text { allergens }\end{array}$} \\
\hline & & $\mathrm{N}$ & $\%$ & N & $\%$ & N & $\%$ \\
\hline \multicolumn{4}{|l|}{ Exposure status: } & 4 & 4.9 & 19 & 23.2 \\
\hline Never exposed & 140 & 2 & 1.4 & 2 & 1.4 & 34 & 24.3 \\
\hline Currently exposed & 479 & 13 & 2.7 & 17 & 3.5 & 140 & 29.2 \\
\hline \multicolumn{8}{|l|}{ Duration of employment in wood industry ${ }^{b}$} \\
\hline $\begin{array}{l}<5 \text { years } \\
5-10 \text { vears }\end{array}$ & 158 & 3 & 1.9 & 3 & 1.9 & 48 & 30.4 \\
\hline$>10-18$ years & 172 & 2 & 1.2 & 5 & 2.9 & 48 & 27.9 \\
\hline$>18$ years & 145 & 7 & 4.8 & 6 & 4.1 & 35 & 24.1 \\
\hline \multicolumn{8}{|l|}{ Exposure level 1997-1998, inhalable dust, mg/m³ } \\
\hline $0-0.72 \mathrm{mg} / \mathrm{m}^{3}$ & 208 & 6 & 2.9 & 5 & 2.4 & 55 & 26.4 \\
\hline $\begin{array}{l}>0.12-1.15 \mathrm{mg} / \mathrm{m}^{3} \\
>1.15 \mathrm{mg} / \mathrm{m}^{3}\end{array}$ & 54 & 7 & 7.4 & 4 & 7.4 & 14 & 25.9 \\
\hline Exposure $2003-05$, inhalable dust, $\mathrm{mg} / \mathrm{m}^{3}$ & $113^{a}$ & 1 & 0.9 & 0 & & 25 & 22.1 \\
\hline $0-0.47 \mathrm{mg} / \mathrm{m}^{3}$ & 235 & 4 & 1.7 & 6 & 2.6 & 79 & 33.6 \\
\hline $\begin{array}{l}>0.47-0.64 \mathrm{mg} / \mathrm{m}^{3} \\
>0.64 \mathrm{mg} / \mathrm{m}^{3}\end{array}$ & 102 & $8^{c}$ & 7.8 & $10^{c}$ & 9.8 & 32 & 31.4 \\
\hline
\end{tabular}

a Reference.

b Only woodworkers.

c Significant trend: Pearson $\chi^{2}$ test between groups: $\mathrm{P}<0.01$.

Table 4. Associations between wood dust sensitization (pine, beech, proteinogenic beech) and respiratory symptoms in logistic regression. All final models included gender, age, smoking and atopy. [OR=0dds ratio; $95 \% \mathrm{Cl}=95 \%$ confidence interval.]

\begin{tabular}{|c|c|c|c|c|c|c|c|c|c|c|}
\hline & \multicolumn{2}{|c|}{$\begin{array}{l}\text { Current } \\
\text { asthma a } \\
(\mathrm{N}=386)\end{array}$} & \multicolumn{2}{|c|}{$\begin{array}{l}\text { Asthma } \\
\text { symptoms } \\
(\mathrm{N}=551)\end{array}$} & \multicolumn{2}{|c|}{$\begin{array}{c}\text { Work-related } \\
\text { asthma symptoms a } \\
(\mathrm{N}=328)\end{array}$} & \multicolumn{2}{|c|}{$\begin{array}{l}\text { Rhinitis } \\
\text { symptoms a }^{\text {a }} \\
(\mathrm{N}=504)\end{array}$} & \multicolumn{2}{|c|}{$\begin{array}{l}\text { Work-related } \\
\text { rhinitis } \\
\text { symptoms a } \\
(\mathrm{N}=376)\end{array}$} \\
\hline & $\mathrm{OR}$ & $95 \% \mathrm{Cl}$ & $\mathrm{OR}$ & $95 \% \mathrm{Cl}$ & $\mathrm{OR}$ & $95 \% \mathrm{Cl}$ & $\mathrm{OR}$ & $95 \% \mathrm{Cl}$ & $\mathrm{OR}$ & $95 \% \mathrm{Cl}$ \\
\hline \multicolumn{11}{|c|}{ Proteinogenic and glycogenic pine epitopes } \\
\hline Specific IgE pine & 2.3 & $0.5-10.0$ & 0.9 & $0.3-3.5$ & 1.3 & $0.2-6.3$ & 1.0 & $0.3-3.7$ & 0.9 & $0.2-4.4$ \\
\hline Smoking ${ }^{b}$ & 1.3 & $0.8-2.0$ & 2.0 & $1.4-2.9$ & 1.8 & $1.0-3.2$ & 1.4 & $1.0-2.0$ & 1.1 & $0.7-1.8$ \\
\hline Atopy ${ }^{c}$ & 3.5 & $2.1-5.8$ & 3.2 & $2.1-4.9$ & 4.2 & $2.2-7.9$ & 2.7 & $1.7-4.2$ & 2.1 & $1.2-3.6$ \\
\hline \multicolumn{11}{|c|}{ Proteinogenic and glycogenic beech epitopes } \\
\hline Specific IgE beech & 0.5 & $0.2-1.6$ & 0.2 & $0.1-0.7$ & 0.6 & $0.1-2.0$ & 0.4 & $0.1-2.1$ & 0.3 & $0.1-1.3$ \\
\hline Smoking ${ }^{b}$ & 1.3 & $0.8-2.1$ & 2.1 & $1.5-3.0$ & 1.8 & $1.0-3.3$ & 1.5 & $1.0-2.1$ & 1.1 & $0.7-1.8$ \\
\hline Atopy ${ }^{c}$ & 4.1 & $2.1-7.1$ & 3.8 & $2.4-6.0$ & 4.8 & $2.5-9.1$ & 3.2 & $2.0-5.1$ & 2.4 & $1.4-4.2$ \\
\hline \multicolumn{11}{|c|}{ Proteinogenic beech epitopes } \\
\hline Specific IgE beech & 1.8 & $0.3-10.3$ & 1.1 & $0.2-6.2$ & 3.2 & $0.5-21.5$ & 1.3 & $0.2-7.1$ & 1.1 & $0 .--8.9$ \\
\hline Smoking b & 1.3 & $0.8-2.0$ & 2.0 & $1.4-2.9$ & 1.8 & $1.0-3.3$ & 1.5 & $1.0-2.0$ & 1.1 & $0.7-1.8$ \\
\hline Atopy ${ }^{c}$ & 3.6 & $2.2-6.0$ & 3.2 & $2.1-4.9$ & 4.0 & $2.1-7.5$ & 2.7 & $1.7-4.1$ & 2.1 & $1.2-3.5$ \\
\hline
\end{tabular}

a Reference: no respiratory symptoms.

${ }^{b}$ Smokers or ex-smokers for $>2$ years prior to the 2003 study.

c Defined as a positive Phadiatop®. 
subjects had a positive sIgE test for pine (14). We are not aware of any epidemiological studies that previously have estimated the prevalence of $\mathrm{sIgE}$ to beech wood, and only a few case reports on beech sensitization have been published. Beech wood is a commonly used type of wood processed in the wood industry.

The epidemiological findings are not directly in line with clinical case series on wood-dust-related asthma or rhinitis that reported around $30 \%$ of the cases to be sensitized to wood dust. For example, Kanerva et al (17) found 13 out of 30 subjects with rhinitis caused by wood dust were confirmed to be positive to at least one skin prick test to wood dust in nasal provocation tests. The clinical cases represent a highly selected group of workers, which may explain the difference in prevalence in the epidemiological studies and the case series. Another explanation might be the type of wood dust. In the Kanerva et al study (17), 9 out of 13 patients were sensitized to obeche wood, which has been proven to have a strong allergenic potential (22). Altogether, our results support previous studies indicating that the allergic potential of pine and beech wood dust is limited.

No difference in sensitization rates were observed according to exposure status (current, prior, or never woodworker) or duration of wood dust exposure. This may be explained by cross-reactivity among plant allergens. In our study population, Kespohl et al (34) showed a high correlation between $\operatorname{sIgE}$ to pine and beech, CCD, and pine pollen ( $\mathrm{r}^{2}$ between $0.59-0.98, \mathrm{P}<0.000$ ), indicating that the primary reason for cross-reactivity among wood dust and pollen may be due to CCD. However, she found no correlation between sIgE concentrations to beech and pine dust, on one hand, and beech or birch pollen on the other $\left(\mathrm{r}^{2}\right.$ between $\left.0.01-0.11, \mathrm{P}>0.05\right)$, which does not support a cross-reactivity based on homolog proteins such as Bet v 1 or Bet v 2. As exposure to wood dust, for example pine and beech, is not uncommon among the general population, it is plausible that some references are sensitized from sources other than work, and on average the occupational exposure does not seem to increase the sensitization rate. On the other hand, we revealed a clear dose-dependent relation between current wood dust level and prevalence of sensitization, with 25 and $31 \%$ of atopics sensitized to pine and beech-dust, respectively, in the highest wood-dust exposed group. Our results indicate that the level of exposure among woodworkers has an impact on the sensitization rate, which has also been observed in other industrial cohorts [eg bakers (36) and lab animal workers (37)].

After adjusting for atopy, no clear relation was seen between wood dust sensitization and respiratory symptoms like asthma and rhinitis. In the 1997 study, sIgE and positive histamine release tests were indeed associated with an increased prevalence of asthma and work-related asthma symptoms $(28,38)$, where Cormier et al (15) found no relation between symptoms, lung function, and sIgE-mediated sensitization to pine wood. There may be several reasons for the variations in associations between $\operatorname{SIgE}$ for wood dust and respiratory symptoms in different studies. It is known from the Kespohl (34) and other studies (28) that the protein in beech and pine wood extracts is generally low, but with large variations. At least for pine wood, it is well known that storage time of wood is closely associated with ongoing protein degradation $(28,39)$. Another reason might be the method of measurement for the IgE-mediated sensitization. Cormier et al (15) used the skin prick test and Skovsted et al (28) used ADVIA ${ }^{\circledR}$ (Siemens AG, Munich, Germany) based on a solid phase with monoclonal anti-human-IgE coupled to paramagnetic particles where our study used ImmunoCAP® 250 (Phadia AB, Uppsala, Sweden) and the specific tailored ImmunoCAP.

Restricting the total $\operatorname{sIgE}$ to proteinogenic $\operatorname{sIgE}$ revealed that only symptomatic subjects in fact had proteinogenic SIgE epitopes to pine dust. For beech dust, the OR of proteinogenic SIgE epitopes increased compared to total sIgE, but did not reach the level of statistical significance. Our interpretation is that the proteinogenic sIgE epitopes have the potential to cause symptoms. Although uncommon (1\%), our results indicate that clinically relevant $\operatorname{sIgE}$ for pine and perhaps beech exist. As far as we know, we are the first to explore the importance of CCD among woodworkers sensitized to wood dust. Our study indicates that only proteinogenic wood dust $\operatorname{sIgE}$ is relevant if the clinical importance is evaluated, but total wood dust sIgE, including both proteinogenic and glycogenic epitopes, are associated with current exposure levels indicating total wood dust sIgE to be a marker for exposure rather than disease.

Our results suggest that sIgE-mediated mechanisms explain, at the most, a minor part of the increased occurrence of respiratory symptoms found in woodworkers, which is in line with results from, for example, western red cedar $(20,21)$, where a non-IgE-mediated specific effect of plicatic acid is very likely. We have earlier investigated IgE-mediated sensitization by skin prick test for both high molecular weight (HMW) $(>10 \mathrm{kDa}$ ) and LMW extract $(<10 \mathrm{kDa})$ of pine and beech dust (40), and we found few positive skin prick test for the low compared to the HMW extracts, which do not support IgE-mediated sensitization to LMW agents to be of major importance, at least for pine and beech. One may speculate if abietic acid, the major constituent in pine resin, could be of importance via a specific non-IgE-mediated pathway, which would be highly relevant to study in the future. Apart from sIgE-mediated sensitization, several other mechanisms are possible. Animal studies have shown that wood components, for example abietic acid, cause direct toxicity via lytic damage to alveolar, tracheal, and bronchial epithelial cells (41). Wood dust extracts from 
both hard and soft wood are able to express and induce the release of inflammatory mediators in human epithelial cell lines (42) and modulate the expression of cytokines and chemokines (43).

Terpenes, a naturally occurring substance in pine and other coniferous trees have also been documented to cause irritation of mucous membranes and increase bronchial responsiveness (44). However, values of total terpenes found in this study were low (GM $\left.7.0 \mathrm{mg} / \mathrm{m}^{3}\right)$ and well below the Danish occupational exposure limit of $140 \mathrm{mg} / \mathrm{m}^{3}$.

There is a range of limitations in the current study. The overall participation rate in both the 1997 and 2003 studies was $67 \%$, which may potentially cause selection bias. We found no difference in baseline respiratory symptoms and mean dust level between participants and non-participants, and also no significant difference in the participation rate between woodworkers and references. Additionally, nearly $80 \%$ of new employees participated in the study. Prior woodworkers seem to have more respiratory symptoms, especially current asthma, compared to current woodworkers, suggesting a healthy worker selection. Of the total included workers, 1701 or $61 \%$ had a blood sample taken. Only $10 \%$ or 276 refused to give blood samples, the rest of the dropout was due to factory closure or absence on the actual day of measurement, primarily due to evening or night shift work, where we did not collect blood samples. Taken together, we do not believe selection bias to be of major importance for the results.

The analyses are in part performed on a study population oversampled with subjects suffering from asthma and rhinitis symptoms. We found no differences with regards to general characteristics (smoking, gender, age) and exposure characteristics for the random sample and the total sample. We therefore judge our results to be representative for the source population, namely current and prior Danish woodworkers.

In conclusion, the quantitative importance of sIgEmediated sensitization to pine and beech wood is limited, but may be of clinical significance for a few workers, especially if the sIgE epitopes are proteinogenic. The sensitization rate for pine and beech dust does not differ between woodworkers and references, but among woodworkers is dependent on the current wood dust exposure level.

\section{Acknowledgements}

We would like to thank Silke Marysa and Ursula Meurer from the Institute of the Ruhr University, Bochum, Germany for their extensive lab work in this project. This study was supported by the Danish Work Environment Foundation, Viborg County, the Danish Medical
Research Council, the Health Insurance Fund, and the Danish Lung Association.

\section{References}

1. Kauppinen T, Vincent R, Liukkonen T, Grzebyk M, Kauppinen A, Welling I, et al. Occupational Exposure to Inhalable Wood Dust in the Member States of the European Union. Ann Occup Hyg. 2006;50(6):549-61.

2. International Agency for Research on Cancer (IARC). Wood Dust and Formaldehyde. IARC monographs on the evaluation of carcinogenic risks to humans. Volume 62. Lyon: IARC; 1995.

3. Luce D, Leclerc A, Bégin D, Demers PA, Gérin M, Orlowski E et al, Sinonasal cancer and occupational exposures: a pooled analysis of 12 case-control studies. Cancer Causes Control. 2002;13:147-57.

4. Chan-Yeung M, Ashley MJ, Corey P, Willson G, Dorken E, Grzybowski S. A respiratory survey of cedar mill workers. I. Prevalence of symptoms. J Occup Med. 1978;20:323-7.

5. Bohadana AB, Massin N, Wild P, Toamain JP, Engel S, Goutet P. Symptoms, airway responsiveness, and exposure to dust in beech and oak wood workers. Occup Environ Med. 2000;57:268-73.

6. Douwes J, McLean D, Slater T, Pearce N. Asthma and Other Respiratory Symptoms in New Zealand Pine Processing Sawmill Workers. Am J Ind Med. 2001;38:608-15.

7. Åhman M, Holmstrom M, Cynkier I, Soderman E. Work related impairment of nasal function in Swedish woodwork teachers. Occup Environ Med. 1996;53:112-7.

8. Holness DL, Sass-Kortsak AM, Pilger CW, Nethercott JR. Respiratory function and exposure-effect relationships in wood dust-exposed and control workers. J Occup Med. 1985;27:501-6.

9. Noertjojo HK, Dimich-Ward H, Peelen S, Dittrick M, Kennedy SM, Chan-Yeung M. Western red cedar dust exposure and lung function: a dose- response relationship. Am J Respir Crit Care Med. 1996;154:968-73.

10. Mandryk J, Alwais KU, Hocking AD. Work-Related Symptoms and Dose-Response Relationships for Personal Exposures and Pulmonary Function Among Woodworkers. Am J Ind Med. 1999;35:481-90.

11. Garces SM, Blanco-Carmona JG, Juste PS, Rodriguez-Gaston P, Perez-Gimenez R, Alonso-Gil L. Occupational asthma and contact urticaria caused by mukali wood dust (Aningeria robusta). J Investig Allergol Clin Immunol. 1995;5:113-4.

12. Basomba A, Burches E, Almodovar A, De-Rojas DH. Occupational rhinitis and asthma caused by inhalation of Balfourodendron riedelianum (Pau Marfim) wood dust. Allergy. 1991;46:316-8.

13. Hernandez M, Sönchez-Hernandez MC, Moreno V, Guardia P, Delgardo J, Maranón F, et al. Occupational rhinitis caused by beech wood dust. Allergy. 1999;54:401-8. 
14. Åhman M, Hage-Hamsten M, Johansson SGO. IgE-mediated allergy to wood dusts probably doers not explain the high prevalence of respiratory symptoms among Swedish woodwork teachers. Allergy. 1995;50:559-62.

15. Cormier Y, Merlaux A, Duchaine C. Respiratory Health Impact of Working in Sawmills in Eastern Canada. Arch Environ Health. 2000;55:424-30.

16. Carosso A, Ruffino C, Bugiani M. Respiratory diseases in wood workers. Br J Ind Med. 1987;44:53-6.

17. Kanerva L, Vaheri E. Occupational allergic rhinitis in Finland. Int Arch Occup Environ Health. 1993;64:565-8.

18. Chan-Yeung M, Barton GM, Maclean L, Grzybowski S. Occupational asthma and rhinitis due to Western red cedar (Thuja plicata). Am Rev Respir Dis. 1973;108:1094-102.

19. Tse KS, Chan H, Chan-Yeung M. Specific IgE antibodies in workers with occupational asthma due to western red cedar. Clin Allergy. 1982;12:249-58.

20. Chan-Yeung M. Mechanism of occupational asthma due to western red cedar (Thuja plicata). Am J Ind Med. 1994;25:13-8.

21. Frew A, Chang JH, Chan H, Quirce S, Noertjojo K, Keown $\mathrm{P}$, Chan-Yeung M. T-lymphocyte responses to plicatic acidhuman serum albumin conjugate in occupational asthma caused by western red cedar. J Allergy Clin Immunol. 1998;101:841-7.

22. Kespohl S, Sander I, Merget R, Petersen A, Meyer HE, Sickmann A, et al. Identification of an obeche (Triplochiton scleroxylon) wood allergen as a class I chitinase. Allergy. 2005;60:808-14.

23. Schlünssen V, Schaumburg I, Andersen NT, Sigsgaard T, Pedersen OF. Nasal Patency is related to dust exposure in woodworkers. Occup Environ Med. 2002; 59:23-9.

24. Schlünssen V, Schaumburg I, Taudorf E, MikkelsenAB, Sigsgaard T. Respiratory Symptoms and Lung Function among Danish Woodworkers. J Occup Environ Med. 2002;44:82-98.

25. Schlünssen V, Schaumburg I, Heederik D, Taudorf E, Sigsgaard T. Indices of asthma among atopic and non-atopic woodworkers. Occup Environ Med. 2004;61:504-11.

26. Schlünssen V, Sigsgaard T, Schaumburg I, Kromhout H. Cross-shift changes in FEV1 in relation to wood dust exposure: the implications of different exposure assessment methods. Occup Environ Med. 2004;61:824-30.

27. Jacobsen G, Schlünssen V, Schaumburg I, Sigsgaard $\mathrm{T}$. Increased incidence of respiratory symptoms among female woodworkers exposed to dry wood. Eur Respir J. 2009;33:1268-76.

28. Skovsted TA, Schlünssen V, Schaumburg I, Wang P, StaunOlsen P, Skov PS. Only few workers exposed to wood dust are detected with specific IgE against pine wood. Allergy. 2003;58:772-9.

29. Jacobsen G. Respiratory diseases and exposure in the Danish Furniture Industry: A 6 year follow-up. Aarhus [dissertation] (Denmark): Faculty of Health Sciences, Aarhus University; 2007.

30. British Medical Research Council Committee on the etiology of chronic bronchitis. Definition and classification of chronic bronchitis for clinical and epidemiological purposes. Lancet. 1965;1:775-9.

31. Burney PG, Luczynska C, Chinn S, Jarvis D. The European Community Respiratory Health Survey. Eur Respir J. 1994;7:954-60.

32. Vinzents PS. A passive personal dust monitor. Ann Occup Hyg 1996;40:261-80.

33. Schlünssen V, Vinzents PS, Mikkelsen AB, Schaumburg I. Wood dust exposure in the Danish Furniture Industry using conventional and passive monitors. Ann Occup Hyg. 2001;45:157-64.

34. Kespohl S, Schlünssen, Jacobsen G, Schaumburg I, Maryska S, Meurer U, Brüning T, Sigsgaard T, Raulf-Heimsoth M. Impact of cross-reactive carbohydrate determinants on wood dust sensitization. Clin Exp Allergy. 2010 Jul;40(7):1099106. Epub 2010 Apr 28.

35. Sander I, Kespohl S, Merget R, Goldscheid N, Degens PO, Bruning T, Raulf-Heimsoth M. A new method to bind allergens for the measurement of specific IgE antibodies. Int Arch Allergy Immunol. 2005;136:39-44.

36. Houba R, Heederik D, Doekes G. Wheat sensitization and work-related symptoms in the baking industry are preventable. An epidemiologic study. Am J Respir Crit Care Med.1998;158:1499-1503.

37. Nieuwenhuijsen MJ, Putcha V, Gordon S, Heederik D, Venables KM, Cullinan P, Newman-Taylor AJ. Exposureresponse relations among laboratory animal workers exposed to rats. Occup Environ Med. 2003;60:104-8.

38. Schlünssen V, Skovsted TA, Schaumburg I, Skov PS, Sigsgaard T. Wood dust sensitization among Danish woodworkers. Am J Ind Med. 2004;46:408-9.

39. Adelsberger U, Petrowitz HJ. Amount and Composition of Proteins of Pine Sapwood (Pinus-Sylvestris L) Stored with Different Long Periods. Holzforschung. 1976;30:109-13.

40. Skovsted TA. Påvisning af allergener og sensibilisering mod træstøv [Assessing allergens and sensitisation against wood dust]. Odense (Denmark): Faculty of Health Sciences, Odense University; 2007

41. Ayars GH, Altman LC, Frazier CA, Chi EY. The toxicity of constituents of cedar and pine woods to pulmonary epithelium. J Allergy Clin Immunol. 1989;83:610-18.

42. Bornholdt J, Saber AT, Sharma AK, Savolainen K, Vogel U, Wallin H. Inflammatory response and genotoxicity of seven wood dusts in the human epithelial cell line A549. Mutat Res. 2007;632:78-88.

43. Maatta J, Luukkonen R, Husgafvel-Pursiainen K, Alenius H, Savolainen K. Comparison of hardwood and softwood dustinduced expression of cytokines and chemokines in mouse macrophage RAW 264.7 cells. Toxicology. 2006;218:13-21.

44. Kasanen JP, Pasanen AL, Pasanen P, Liesivuori J, Kosma VM, Alarie Y. Evaluation of sensory irritation of delta3-carene and turpentine, and acceptable levels of monoterpenes in occupational and indoor environment. J Toxicol Environ Health A. 1999;57:89-114.

Received for publication: 19 December 2009 